\title{
Francesco Benci
}

Francesco Benci's Quinque Martyres. Introduction, Translation, and Commentary by Paul Gwynne. Jesuit Studies, volume 12. Leiden: Brill, 2017. Pp. xiv + 739. Hb, \$170.

This is the first volume in a new and timely bilingual neo-Latin/English text series, "Jesuit Neo-Latin Library," published by Brill. Jesuit Latin represents a vast inland sea within the mare magnum of early modern Latinity, well worth exploration by classicists and modern linguists as well as by historians of the Society of Jesus. Francesco Benci's Five martyrs (in six books) is the first of a new kind of exemplary neo-Latin epic, which not only served as a template for the teaching of Latin heroic verse in Jesuit colleges but also as a recruitment tool for the Jesuit missions. It commemorates the recent martyrdom of five Jesuits, led by Rodolfo Acquaviva (1550-83), nephew of the Jesuit superior general, at Cuncolim in Southern India in 1583 . Benci himself did not see active service as a missionary, but was professor of rhetoric at the Roman College, and a star pupil of the French humanist, Marc-Antoine Muret. His epic poem, published in Venice in 1591 and corrected and reprinted by the Vatican Press the following year, is chiefly modelled on Virgil's Aeneid, with local borrowings from Lucretius, Lucan, Statius, Prudentius, and neo-Latin writers such as Marco Girolamo Vida and Girolamo Fracastoro.

The present volume is divided into two parts, with the first comprising a series of short introductory chapters on the historical background, Benci's relationship to the epic tradition, his imitation of Virgil and Renaissance neoLatin epic, the reception of the poem, and rhetorical features such as amplificatio and ekphrasis. A useful synopsis reveals, at a glance, both the classicism and novelty of the work: its epideictic form, overt didacticism, and typically Jesuit appeal to the emotions and senses. The descriptions of the martyrs are related to contemporary artistic programs, such as the thirty-two scenes of early Christian martyrs realized by Niccolò Circignani (c.1530-97) in his gruesome frescoes for the church of Santo Stefano Rotondo in Rome, which were themselves conceived as aids to meditation and prayer. Gwynne highlights the visuality of Benci's poem and convincingly relates it to Jerónimo Nadal's Adnotationes et meditationes in evangelia quae in sacrosancto Missae sacrificio toto anno leguntur (Antwerp: Martin Nuntius, 1594), an illustrated collection of Gospel meditations commissioned by Ignatius of Loyola, as well as to contemporary manuscript collections of student verse on art at the Roman College. Book Four contains an epyllion on the life of Christ, recounted by Rodolfo Acquaviva during a pause on the missionaries' journey to Salcete, and in the context of a report on the religious debates at the court of the Mughal king Akbar in northern India. Not only does this epyllion distil the theme of Vida's 
Christiad, it parallels the inclusion in Vida's fourth book of an epyllion, there related by the apostle John to Pilate, on Christ's teaching and ministry.

The second part of Gwynne's volume contains the text, translation, and commentary, and is rounded out by five appendices, including the mission reports on which the martyrdom narrative is based. The translation is accurate and fluent and the commentary provides all the cultural and historical thick description necessary for the relatively novice reader of this multi-layered Jesuit text, including biblical allusions. There are long stretches where Gwynne merely indicates where Benci has "lifted" a line or half line from this or that classical or late antique author, but this is not to be counted as a defect. Gwynne has opted to document, as economically as possible in a volume of already substantial proportions, Benci's centonic and magpie-like compositional technique. As he announces in his chapter on Benci and Virgil: "we must imagine Benci sifting, physically or mentally, through the works of Virgil for an apposite verse, preferably a line end, and then adapting it to his present needs" (53).

It is surprising that the literary career of so interesting and well-connected a figure as Benci-a contemporary of Renaissance Latin epic poets Lorenzo Gambara (author of the De navigatione Christophori Columbi [Rome: F. Zanetti, 1581]) and Pier Angèli da Barga (author of the Syrias [Florence: Iunctius, 1591]) and a bridge between them and the vernacular Christian epic of Torquato Tasso-is not better known, nor represented by a volume in the I Tatti Renaissance Library (Harvard University Press). As Gwynne reveals, Benci's epic was an instant success and enjoyed a healthy and fascinating afterlife, both within and beyond the Jesuit order. He tantalizingly concludes his chapter on the reception with the observation that "many lines in the various Latin versions of Paradise Lost bear a striking similarity to the Quinque martyres" (103). It is worth recalling that a later Jesuit Latin epic, Jacob Masen's Sarcotis (first published in the third tome of his Palaestra eloquentiae ligatae [Cologne: 1654]), was disingenuously alleged by eighteenth-century Scot, William Lauder, to have been plagiarized by Milton!

Gwynne's edition is multiple-user-friendly and may be profitably consulted by students of the classical tradition and neo-Latin literature (for whom a rich panoply of Latin parallels is provided but not translated) as well as of early modern Catholicism and the Asian missions (for whom relevant titles and quotations are more or less all translated). Its one significant production flaw is the absence of book numbers in the running heads of the commentary, making navigation back and forth from the corresponding text somewhat difficult. One hopes that this problem will be corrected in future volumes in the series. For the historian of the Society of Jesus, Gwynne's volume is a valuable 
contribution to our understanding of educational and ideological programs at the very beginning of the order-the poem was published just eight years before the Ratio studiorum - and provides an important point of reference for consideration of later Jesuit epic.

\author{
Yasmin Haskell \\ University of Bristol \\ yh1678o@bristol.ac.uk \\ DOI:10.1163/22141332-00504010-12
}

